\title{
Stability of Extemporaneously Compounded Dexamethasone in Glass and Plastic Bottles and Plastic Syringes
}

\author{
Mary H H Ensom and Diane Décarie
}

\begin{abstract}
Background: Dexamethasone is widely used to treat rheumatic and endocrine disorders and chemotherapy-induced nausea and vomiting. A palatable, alcohol-free liquid formulation, with a suitable concentration to allow reasonable administration volume, is available only via extemporaneous compounding.
\end{abstract}

Objective: To evaluate the stability of dexamethasone suspensions in commercially available vehicles (Oral Mix and Oral Mix SF) in various types of containers after storage at $25^{\circ} \mathrm{C}$ and $4{ }^{\circ} \mathrm{C}$ for up to 91 days.

Methods: Dexamethasone suspensions $(1 \mathrm{mg} / \mathrm{mL})$ were prepared in Oral Mix and Oral Mix SF and then transferred to amber glass and plastic prescription bottles and plastic oral syringes. Suspensions in all 3 types of containers were stored at $25^{\circ} \mathrm{C}$; suspensions in glass and plastic bottles were also stored at $4^{\circ} \mathrm{C}$. Samples were collected weekly from each container up to 28 days and then every 2 weeks up to 91 days. The samples were analyzed by a validated, stability-indicating high-performance liquid chromatography - ultraviolet detection method. A suspension was considered stable if it maintained at least $90 \%$ of its initial dexamethasone concentration. Changes in colour, taste, odour, precipitation (and ease of resuspension), and $\mathrm{pH}$ were used to assess physical compatibility.

Results: All suspensions maintained at least $96 \%$ of the original concentration for up to 91 days with storage at $25^{\circ} \mathrm{C}$ or at $4^{\circ} \mathrm{C}$. No notable changes in colour, taste, odour, precipitation, or $\mathrm{pH}$ were observed over the 91-day period.

Conclusion: Dexamethasone suspensions $(1 \mathrm{mg} / \mathrm{mL})$ in Oral Mix and Oral Mix SF, stored in amber glass or plastic bottles or plastic syringes at $25^{\circ} \mathrm{C}$ or in amber glass or plastic bottles at $4^{\circ} \mathrm{C}$ can be expected to remain stable for up to 91 days.

Keywords: dexamethasone, suspension, stability, high-performance liquid chromatography

\section{Can J Hosp Pharm. 2014;67(4):274-9}

\section{RÉSUMÉ}

Contexte : La dexaméthasone est couramment utilisée pour traiter les affections endocriniennes et rhumatismales ainsi que les nausées et vomissements causés par la chimiothérapie. Mais, une forme liquide sans alcool, au goût acceptable et d'une concentration suffisante pour permettre l'administration d'un volume acceptable de médicament ne peut être obtenue que par la réalisation d'une préparation extemporanée. Objectif : Évaluer la stabilité de suspensions de dexaméthasone préparées dans des excipients disponibles sur le marché (Oral Mix et Oral Mix SF) et placées dans différents types de contenant après leur entreposage à $4{ }^{\circ} \mathrm{C}$ et à $25^{\circ} \mathrm{C}$ pendant une période allant jusqu’à 91 jours.

Méthodes : Des suspensions de dexaméthasone $(1 \mathrm{mg} / \mathrm{mL})$ ont été préparées dans des excipients Oral Mix et Oral Mix SF, puis transférées dans des seringues orales de plastique ambré et dans des flacons pour médicaments d'ordonnance en plastique et en verre ambrés. Des suspensions contenues dans les trois types de contenant ont été entreposées à $25^{\circ} \mathrm{C}$, alors que seules des préparations contenues dans des flacons de verre et de plastique ont aussi été entreposées à $4{ }^{\circ} \mathrm{C}$. Des échantillons ont été prélevés de chaque contenant une fois par semaine jusqu'à 28 jours, puis toutes les deux semaines jusqu'à 91 jours. Les échantillons ont été analysés à l'aide d'une épreuve validée mesurant la stabilité par chromatographie liquide haute performance avec détection ultraviolette. Une suspension était jugée stable si elle conservait au moins $90 \%$ de sa concentration initiale de dexaméthasone. Tout changement dans la couleur, le goût, l'odeur, le $\mathrm{pH}$ ainsi que la formation de précipité (et la facilité de remise en suspension) a servi à l'évaluation de la compatibilité physique.

Résultats : Toutes les suspensions ont conservé au moins $96 \%$ de leur concentration initiale pendant une période allant jusquà 91 jours dans des conditions d'entreposage de $25^{\circ} \mathrm{C}$ ou de $4{ }^{\circ} \mathrm{C}$. Aucun changement notable de couleur, de goût, d'odeur, de formation de précipité ou de $\mathrm{pH}$ n'a été observé pendant la période de 91 jours.

Conclusion : Les préparations de dexaméthasone en suspension $(1 \mathrm{mg} / \mathrm{mL})$ dans les bases Oral Mix et Oral Mix SF conservées dans des seringues de plastique ambré ou dans des flacons pour médicaments d'ordonnance en plastique ou en verre ambrés à $25^{\circ} \mathrm{C}$ ainsi que celles conservées dans des flacons pour médicaments d'ordonnance en plastique ou en verre ambrés à $4^{\circ} \mathrm{C}$ devraient demeurer stables pendant une période allant jusqu’à 91 jours.

Mots clés : dexaméthasone, suspension, stabilité, chromatographie liquide haute performance

[Traduction par l'éditeur] 


\section{INTRODUCTION}

$T^{\prime}$ he adrenocorticosteroid dexamethasone is widely used to treat rheumatic and endocrine disorders and chemotherapyinduced nausea and vomiting. ${ }^{1}$ Current commercially available liquid preparations of dexamethasone are unsuitable for many children: the concentrated solutions and elixirs contain $30 \%$ alcohol, and the $0.1 \mathrm{mg} / \mathrm{mL}$ strength of the nonconcentrated solution requires large-volume doses.,3

Chou and others ${ }^{3}$ found that extemporaneously compounded dexamethasone suspensions $(0.5$ and $1 \mathrm{mg} / \mathrm{mL})$ in a 1:1 mixture of Ora-Sweet and Ora-Plus vehicle were physically and chemically stable for up to 91 days when stored in amber plastic bottles at room temperature or under refrigeration.

The purpose of the current study was to expand upon those previous findings ${ }^{3}$ by ascertaining the physical and chemical stability of dexamethasone suspensions $1 \mathrm{mg} / \mathrm{mL}$ in other commercially available vehicles (specifically Oral Mix and Oral Mix SF) after storage in amber glass and plastic bottles and plastic syringes at $25^{\circ} \mathrm{C}$ (room temperature) or in amber glass and plastic bottles at $4^{\circ} \mathrm{C}$ (refrigerated) for up to 91 days.

\section{METHODS}

\section{Preparation of Dexamethasone and Experimental Set-up}

Stock suspensions of dexamethasone $1 \mathrm{mg} / \mathrm{mL}$ were prepared by diluting commercially available dexamethasone $4 \mathrm{mg} / \mathrm{mL}$ for injection (Sandoz Canada, Boucherville, Quebec; lot CM0518, expiry May 2014) in Oral Mix and Oral Mix SF vehicles (Medisca Inc, Plattsburgh, New York; lots 1074/A and 1071/A, respectively). Each suspension was divided among 6 amber glass bottles (Richards Distribution, Richmond, British Columbia), 6 amber plastic polyethylene terephthalate (PET) prescription bottles (Richards Distribution), and twenty-five 5-mL amber plastic oral syringes (PreciseDose Dispenser System, Medisca Inc; lot 46959/C). Three glass bottles and 3 plastic bottles of each suspension were kept at room temperature $\left(25^{\circ} \mathrm{C}\right)$, with the other 3 glass and plastic bottles of each suspension being refrigerated $\left(4^{\circ} \mathrm{C}\right)$. All of the syringes were kept at $25^{\circ} \mathrm{C}$.

\section{Physical Compatibility}

The physical characteristics of the suspensions were evaluated at the time of preparation, at weekly intervals up to 28 days, and then at 2-week intervals up to 91 days. At each time point, all samples were examined for obvious changes in colour, taste, odour, precipitation, and ease of resuspension. One 3-mL sample from each bottle and the contents of 3 syringes from each group were collected for determination of $\mathrm{pH}$. The $\mathrm{pH}$ meter (model 8000, VWR International, Mississauga, Ontario) was calibrated at the beginning of each testing session with commercially available standards (Fisher Scientific, Whitby, Ontario; pH 7.00, lot 116554; pH 4.00, lot 116550; expiry November 2013 for both). Immediately following these physical observations, a 1.0-mL sample from each bottle or syringe was transferred to a threaded, tight-seal cryogenic polypropylene vial (VWR International) and stored for a maximum of 120 days at $-85^{\circ} \mathrm{C}$ until analysis by a validated, stability-indicating, high-performance liquid chromatography (HPLC) - ultraviolet detection method.

\section{Chemical Stability Preparation of Stocks, Standards, and Standard Curve}

Stock solutions of dexamethasone $1.0 \mathrm{mg} / \mathrm{mL}$ were prepared in HPLC-grade methanol (Fisher Scientific; lot 134319) from dexamethasone for injection (Sandoz Canada; lot CP0562, expiry June 2014) to construct a standard curve. $6 \alpha$-Methylprednisolone powder (Sigma-Aldrich, Oakville, Ontario; lot BCBH9056V) diluted in HPLC-grade methanol to a concentration of $1.0 \mathrm{mg} / \mathrm{mL}$ was selected as the internal standard.

Standards were prepared from stock solutions as follows. Dexamethasone standard solutions containing $0.150 \mathrm{mg} / \mathrm{mL}$ of the internal standard were prepared in HPLC-grade water (Fisher Scientific; lot 135622) to final concentrations of $0.020,0.030$, $0.040,0.050,0.060$, and $0.070 \mathrm{mg} / \mathrm{mL}$. All standards were passed through a GHP (Gelman hydrophilic propylene) $13 \mathrm{~mm}$ diameter, 0.45- $\mu \mathrm{m}$ microfilter (Acrodisc, Waters Corporation, Mississauga, Ontario; lot 21786983) to prevent injection of impurities onto the column.

Using these standards, a 6-point calibration curve was prepared, with a blank (water only) at the beginning of each run, to ensure no carry-over from one run to the next. The range of this calibration curve $(0.020$ to $0.070 \mathrm{mg} / \mathrm{mL})$ encompassed the diluted test concentration of dexamethasone (i.e., $0.050 \mathrm{mg} / \mathrm{mL}$ ). The calibration curve was generated by least-squares regression of the peak area ratio of dexamethasone to $6 \alpha$-methylprednisolone (the internal standard) and the concentration of each dexamethasone standard.

The precision of the assay was evaluated by intraday and interday validation methods. The intraday variability was determined by running various concentrations of the standards $(0.020,0.044,0.054$, and $0.064 \mathrm{mg} / \mathrm{mL}$, respectively) in quadruplicate throughout a single day. The interday variability was determined by running the same analyte concentrations in quadruplicate daily for 4 days. Accuracy of the assay was calculated as the mean deviation between nominal and observed concentrations. The means, standard deviations, and coefficients of variation were calculated. Acceptable limits for the coefficients of variation for precision were defined a priori as less than $10 \%$, and acceptable limits for accuracy were defined as greater than $90 \%$.

\section{HPLC Instrumentation}

The HPLC instrumentation (model 2690, Waters Alliance System, Waters Corporation) consisted of a delivery pump, an automatic injector equipped with a $200-\mu \mathrm{L}$ injector, a Symmetry 
C18 $4.6 \times 100 \mathrm{~mm}$ column (Waters Corporation; lot 0203304913884), a Symmetry C18 $3.9 \times 20 \mathrm{~mm}$ guard column (Waters Corporation; lot 0274330781), and a dual-absorbance ultraviolet detector (model 2487, Waters Alliance System) set at $238 \mathrm{~nm}$. The mobile phase consisted of a 32:68 mixture of acetonitrile (Fisher Scientific; lot 1355590) and $10 \mathrm{mmol} / \mathrm{L}$ ammonium formate buffer (Sigma-Aldrich; lot BCBJ-6906V) at $\mathrm{pH} 5.0$ and room temperature. All solvents were HPLC-grade and were filtered before use. To obtain clear chromatograms, the flow rate was initially set at $1.0 \mathrm{~mL} / \mathrm{min}$ and then increased to $1.5 \mathrm{~mL} / \mathrm{min}$ over a period of $1.5 \mathrm{~min}$.

\section{Accelerated Degradation of Dexamethasone}

Suspensions of dexamethasone $1.0 \mathrm{mg} / \mathrm{mL}$ in Oral Mix and Oral Mix SF were prepared (without internal standard) from dexamethasone $4.0 \mathrm{mg} / \mathrm{mL}$ for injection. Aliquots of the $1.0 \mathrm{mg} / \mathrm{mL}$ suspensions were mixed (v:v) with $2 \mathrm{~N}$ sodium hydroxide $(\mathrm{NaOH})$ or $2 \mathrm{~N}$ hydrochloric acid $(\mathrm{HCl})$, then vortex-mixed and incubated for $24 \mathrm{~h}$ at $90^{\circ} \mathrm{C}$. The samples were cooled to room temperature and centrifuged. Each supernatant was diluted in HPLC-grade water to a final concentration of $0.050 \mathrm{mg} / \mathrm{mL}$, filtered, and injected onto the column. The chromatograms obtained with the degraded samples were compared with a chromatogram obtained from the calibration curve to determine any changes in concentration, retention time, and peak shape.

\section{RESULTS}

The regression analysis of the peak area ratio of dexamethasone to $6 \alpha$-methylprednisolone versus the concentration of each dexamethasone standard demonstrated linearity over the range of concentrations, with coefficient of determination $\left(r^{2}\right) \geq 0.998$ $(n=4)$. The intraday and interday coefficients of variation were within acceptable limits (i.e., < 10\%): 1.96\% and 2.72\%, respectively, for the $0.020 \mathrm{mg} / \mathrm{mL}$ solution; $1.15 \%$ and $0.72 \%$, respectively, for the $0.044 \mathrm{mg} / \mathrm{mL}$ solution; $0.49 \%$ and $0.64 \%$, respectively, for the $0.054 \mathrm{mg} / \mathrm{mL}$ solution; and $1.07 \%$ and $1.08 \%$, respectively, for the $0.064 \mathrm{mg} / \mathrm{mL}$ solution. The intraday and interday accuracy values were also within acceptable limits (i.e., > 90\%): 99.39\% $\pm 0.57 \%$ and $98.25 \% \pm 0.93 \%$, respectively, for the $0.020 \mathrm{mg} / \mathrm{mL}$ solution; $98.87 \% \pm 0.79 \%$ and $99.03 \% \pm 0.99 \%$, respectively, for the $0.044 \mathrm{mg} / \mathrm{mL}$ solution; $99.24 \% \pm 0.74 \%$ and $99.58 \% \pm 0.50 \%$, respectively, for the $0.054 \mathrm{mg} / \mathrm{mL}$ solution; and $98.70 \% \pm 0.47 \%$ and $99.95 \% \pm 0.84 \%$, respectively, for the $0.064 \mathrm{mg} / \mathrm{mL}$ solution.

The retention times for a standard solution (in water) were $0.92 \mathrm{~min}$ for dexamethasone and $3.98 \mathrm{~min}$ for the internal standard (6 $\alpha$-methylprednisolone) (Figure 1A). The same retention times occurred for both dexamethasone and the internal standard with Oral Mix vehicle on day 0 (Figure 1B)
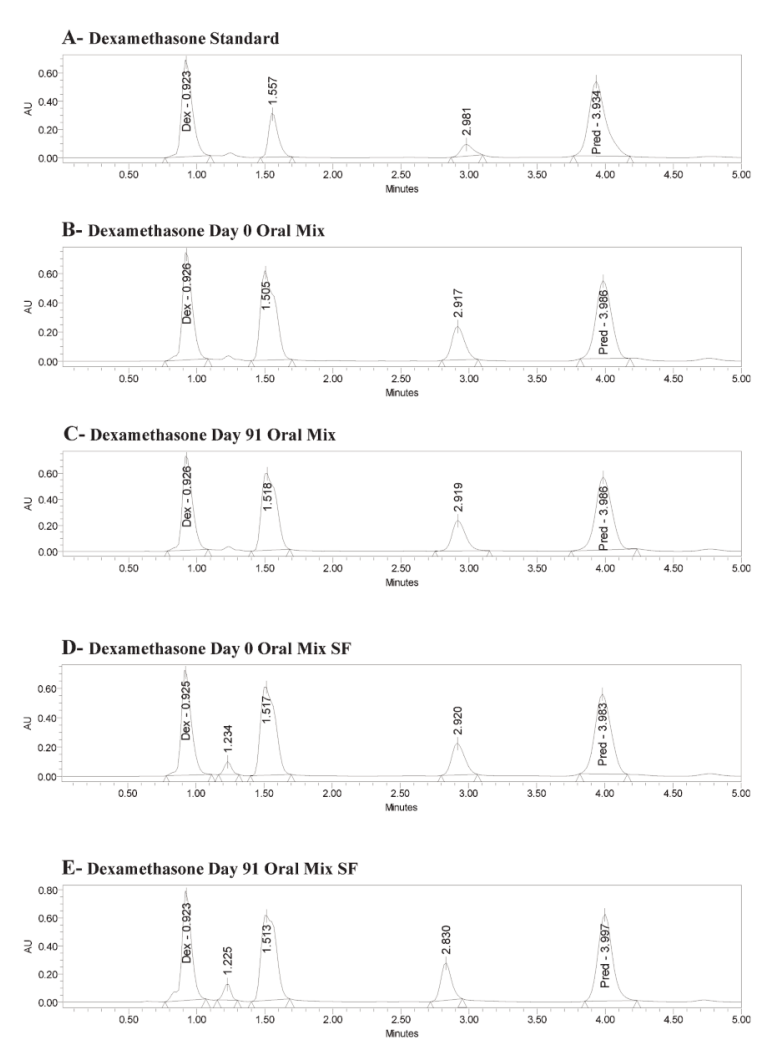

Figure 1. Panel A: Chromatogram of dexamethasone standard, showing peaks for dexamethasone (Dex) at 0.92 min and internal standard ( $6 \alpha$-methylprednisolone; Pred) at 3.98 min. Panels B and C: Dexamethasone in Oral Mix suspension at days 0 and 91 , respectively. Panels $D$ and $E$ : Dexamethasone in Oral Mix SF suspension at days 0 and 91, respectively.

and day 91 (Figure 1C) and with Oral Mix SF vehicle on day 0 (Figure 1D) and day 91 (Figure 1E). No interfering peaks were generated by forced degradation of dexamethasone with $\mathrm{HCl}$ or $\mathrm{NaOH}$ (Figure 2). In general, the dexamethasone peak in Oral Mix vehicle was reduced by $45.2 \%$ when treated with $\mathrm{HCl}$ and by $39.4 \%$ when treated with $\mathrm{NaOH}$, relative to the original dexamethasone chromatogram; in Oral Mix SF vehicle, the dexamethasone peak was reduced by $34.8 \%$ when treated with $\mathrm{HCl}$ and by $68.7 \%$ when treated with $\mathrm{NaOH}$. Minor non-interfering peaks were also observed. The HPLC method developed here was deemed capable of indicating stability.

There were no notable changes in $\mathrm{pH}$. No precipitate formed, and the milky white suspensions were easily resuspended throughout the study period. There were no notable changes in the faint cherry taste or odour of any suspension. Over the study period, the mean $( \pm$ standard deviation $) \mathrm{pH}$ values for the suspensions prepared in Oral Mix were $5.38 \pm 0.08$ (glass bottles), $5.36 \pm 0.08$ (plastic bottles), and $5.36 \pm 0.07$ (oral syringes) stored at $25^{\circ} \mathrm{C}$; and $5.40 \pm 0.08$ (glass bottles) and $5.38 \pm 0.07$ (plastic bottles) stored at $4^{\circ} \mathrm{C}$. The mean $( \pm$ standard deviation) 

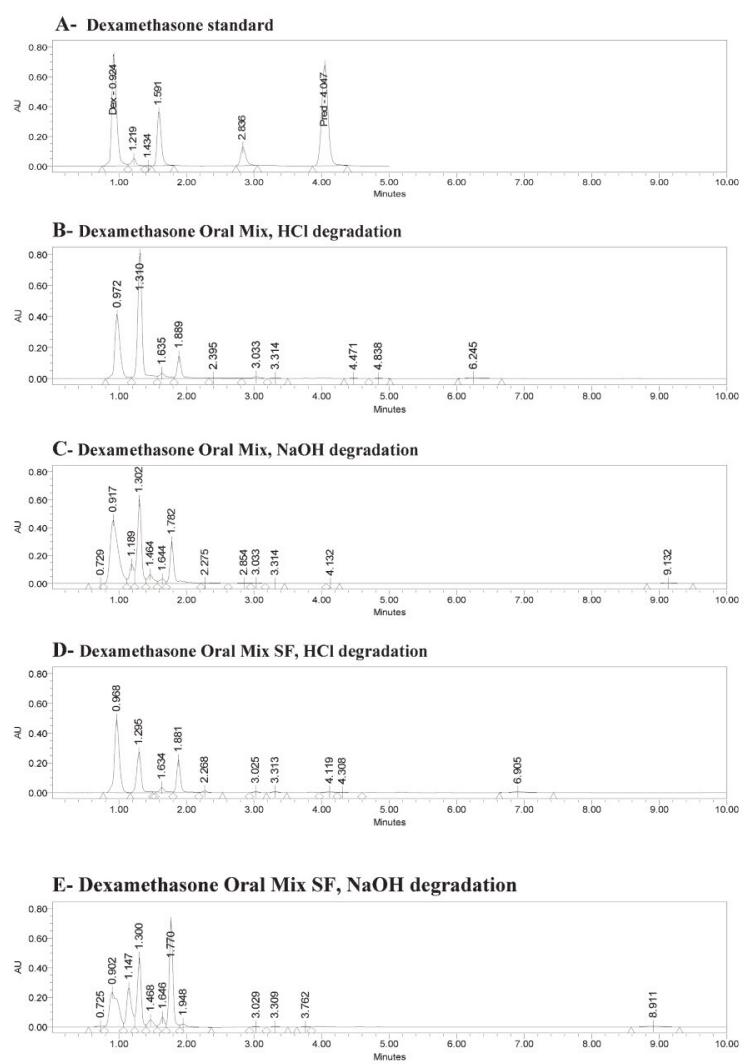

Figure 2. Panel A: Chromatogram of dexamethasone standard, showing peaks for dexamethasone (Dex) at 0.92 min and internal standard ( $6 \alpha$-methylprednisolone; Pred) at 3.98 min. Panels B and C: Dexamethasone in Oral Mix suspension after forced degradation by hydrochloric acid and sodium hydroxide, respectively. Panels D and E: Dexamethasone in Oral Mix SF suspension after forced degradation by hydrochloric acid and sodium hydroxide, respectively. Panels $B$ through $D$ show reductions in the dexamethasone peaks and the presence of minor, non-interfering peaks.

$\mathrm{pH}$ values for the suspensions prepared in Oral Mix SF were 5.43 \pm 0.08 (glass bottles), $5.39 \pm 0.09$ (plastic bottles), and 5.39 \pm 0.08 (oral syringes) stored at $25^{\circ} \mathrm{C}$; and $5.44 \pm 0.08$ (glass bottles) and $5.41 \pm 0.09$ (plastic bottles) stored at $4^{\circ} \mathrm{C}$.

The HPLC analysis showed that all dexamethasone suspensions prepared in Oral Mix or Oral Mix SF and stored at $25^{\circ} \mathrm{C}$ or $4^{\circ} \mathrm{C}$ maintained at least $96 \%$ of their original concentrations for 91 days (Tables 1 and 2).

\section{DISCUSSION}

According to HPLC analyses, dexamethasone suspensions $1 \mathrm{mg} / \mathrm{mL}$ prepared in Oral Mix or Oral Mix SF maintained at least $96 \%$ of their original concentrations for up to 91 days when stored at $25^{\circ} \mathrm{C}$ in amber glass or plastic bottles or plastic syringes or when stored at $4^{\circ} \mathrm{C}$ in amber glass or plastic bottles.

Chou and others ${ }^{3}$ demonstrated physical and chemical stability (for 91 days) of an extemporaneously prepared dexa- methasone suspension in plastic (polyvinyl chloride) prescription bottles, which overcomes the limitations (e.g., alcohol content and administration volume) of the current commercially available liquid preparations of dexamethasone. ${ }^{2}$ The current study was undertaken to ascertain whether stability would be maintained with newer vehicles that have become available since the earlier study, specifically Oral Mix and Oral Mix SF, with storage in amber glass and plastic (PET) prescription bottles and plastic oral syringes. The 1:1 Ora-Sweet - Ora-Plus vehicle used in the study by Chou and others ${ }^{3}$ is equivalent to Ora-Blend, ${ }^{4}$ whereas 1:1 Ora-Sweet SF - Ora-Plus is equivalent to Ora-Blend SF. ${ }^{5}$ A comparison of Oral Mix (used in the current study) with Ora-Blend shows that all the ingredients are identical, except the following: Oral Mix contains sodium citrate and simethicone, ${ }^{6}$ and Ora-Blend contains calcium sulfate, trisodium phosphate, sodium phosphate, and dimethicone antifoam emulsion. ${ }^{4} \mathrm{~A}$ comparison of the sugar-free vehicles, Oral Mix SF (used in the current study) and Ora-Blend SF, shows that all the ingredients are identical, except the following: Oral Mix SF contains simethicone, ${ }^{6}$ and Ora-Blend SF contains calcium sulfate, trisodium phosphate, sodium phosphate, and dimethicone antifoam emulsion. ${ }^{5}$

As in the study by Chou and others, ${ }^{3}$ the current study used dexamethasone for injection rather than tablets for preparation of suspensions. The primary reason was the less-than-desirable palatability of suspensions prepared with crushed tables (which the "taste tester" described as tasting like "wet cardboard"). Another advantage of the injectable solution over the tablets is that the dexamethasone is already dissolved, which eliminates the need for crushing or grinding.

Although the evaluations of physical characteristics (other than $\mathrm{pH}$ ) were qualitative, all observations throughout the 91-day study were documented by the same individual (D.D.), who has many years of experience in conducting stability studies, which eliminated inter-observer bias. Any condensation that occurred in the freezing process would represent another potential study limitation, as dilution of the sample would occur upon thawing. The propylene tubes used for storage at $-85^{\circ} \mathrm{C}$ were airtight and did not allow freeze-drying, a phenomenon that can lead to an increase in drug concentration, apparently masking a loss of concentration. Indeed, the results reported here showed that the concentrations were within an average $2.1 \%$ of the expected concentrations.

\section{CONCLUSIONS}

According to serial qualitative assessment of physical properties and $\mathrm{pH}$, along with serial HPLC analyses, dexamethasone suspensions $(1 \mathrm{mg} / \mathrm{mL})$ in Oral Mix or Oral Mix SF stored in amber glass or plastic bottles or plastic syringes at $25^{\circ} \mathrm{C}$ or stored in amber glass or plastic bottles at $4^{\circ} \mathrm{C}$ are expected to be stable for up to 91 days. 
This single copy is for your personal, non-commercial use only.

For permission to reprint multiple copies or to order presentation-ready copies for distribution, contact CJHP at cjhpedit@cshp.ca

Table 1. Dexamethasone Concentration or Percentage of Initial Concentration Remaining (Mean \pm Standard Deviation) in Oral Mix Suspension Vehicle over 91 Days of Storage in Glass and Plastic Bottles and Plastic Syringes $\left(25^{\circ} \mathrm{C}\right)$ and in Glass and Plastic Bottles $\left(4^{\circ} \mathrm{C}\right)^{*}$

\begin{tabular}{|c|c|c|c|c|c|}
\hline \multirow[b]{2}{*}{ Study Day } & \multicolumn{2}{|c|}{ Glass Bottles } & \multicolumn{2}{|c|}{ Plastic Bottles } & \multirow{2}{*}{$\begin{array}{c}\text { Plastic Syringes } \\
25^{\circ} \mathrm{C}\end{array}$} \\
\hline & $25^{\circ} \mathrm{C}$ & $4^{\circ} \mathrm{C}$ & $25^{\circ} \mathrm{C}$ & $4^{\circ} \mathrm{C}$ & \\
\hline $\begin{array}{l}0 \text { (initial measured concentration; } \\
\mathrm{mg} / \mathrm{mL}) \dagger\end{array}$ & $0.988 \pm 0.006$ & $0.988 \pm 0.006$ & $0.988 \pm 0.006$ & $0.988 \pm 0.006$ & $0.988 \pm 0.0067$ \\
\hline 7 & $98.1 \% \pm 1.8 \%$ & $97.7 \% \pm 1.1 \%$ & $96.0 \% \pm 1.1 \%$ & $96.6 \% \pm 1.0 \%$ & $98.2 \% \pm 2.8 \%$ \\
\hline 14 & $98.4 \% \pm 1.1 \%$ & $100.5 \% \pm 2.1 \%$ & $100.2 \% \pm 2.5 \%$ & $101.4 \% \pm 4.1 \%$ & $97.6 \% \pm 2.1 \%$ \\
\hline 21 & $97.5 \% \pm 2.5 \%$ & $100.2 \% \pm 0.7 \%$ & $101.3 \% \pm 1.9 \%$ & $100.3 \% \pm 2.2 \%$ & $100.1 \% \pm 1.2 \%$ \\
\hline 28 & $98.1 \% \pm 4.2 \%$ & $100.3 \% \pm 3.8 \%$ & $100.3 \% \pm 2.2 \%$ & $100.6 \% \pm 3.5 \%$ & $98.8 \% \pm 1.9 \%$ \\
\hline 35 & $99.9 \% \pm 2.1 \%$ & $98.5 \% \pm 3.6 \%$ & $99.9 \% \pm 2.7 \%$ & $98.1 \% \pm 1.3 \%$ & $98.9 \% \pm 1.5 \%$ \\
\hline 49 & $97.9 \% \pm 2.3 \%$ & $100.1 \% \pm 1.6 \%$ & $100.5 \% \pm 2.9 \%$ & $98.2 \% \pm 2.3 \%$ & $98.3 \% \pm 1.3 \%$ \\
\hline 63 & $99.6 \% \pm 2.4 \%$ & $99.0 \% \pm 3.1 \%$ & $100.0 \% \pm 1.1 \%$ & $100.2 \% \pm 0.7 \%$ & $100.3 \% \pm 1.2 \%$ \\
\hline 77 & $101.8 \% \pm 4.5 \%$ & $98.3 \% \pm 1.6 \%$ & $98.1 \% \pm 2.0 \%$ & $98.7 \% \pm 2.1 \%$ & $97.5 \% \pm 1.1 \%$ \\
\hline In mg/mL & $\begin{array}{l}1.006 \pm 0.045 \\
(101.8 \%)\end{array}$ & $\begin{array}{l}0.971 \pm 0.016 \\
(98.3 \%)\end{array}$ & $\begin{array}{l}0.969 \pm 0.020 \\
(98.1 \%)\end{array}$ & $\begin{array}{l}0.975 \pm 0.021 \\
(98.7 \%)\end{array}$ & $\begin{array}{l}0.963 \pm 0.011 \\
(97.5 \%)\end{array}$ \\
\hline 91 & $98.1 \% \pm 2.4 \%$ & $99.8 \% \pm 1.3 \%$ & $99.9 \% \pm 1.7 \%$ & $99.9 \% \pm 1.7 \%$ & $98.7 \% \pm 0.9 \%$ \\
\hline In mg/mL & $\begin{array}{l}0.969 \pm 0.024 \\
(98.1 \%)\end{array}$ & $\begin{array}{l}0.986 \pm 0.013 \\
(99.8 \%)\end{array}$ & $\begin{array}{l}0.987 \pm 0.017 \\
(99.9 \%)\end{array}$ & $\begin{array}{l}0.986 \pm 0.017 \\
(99.9 \%)\end{array}$ & $\begin{array}{l}0.975 \pm 0.009 \\
(98.7 \%)\end{array}$ \\
\hline
\end{tabular}

*Measured concentration on days 0,77 , and 91 is reported as mean \pm standard deviation of 3 samples, analyzed in duplicate. Percent of initial measured concentration on all study days was calculated from the mean \pm standard deviation of 3 samples, analyzed in duplicate.

†Nominal initial concentration of all suspensions was $1.0 \mathrm{mg} / \mathrm{mL}$

Table 2. Dexamethasone Concentration or Percentage of Initial Concentration Remaining (Mean \pm Standard Deviation) in Oral Mix SF Suspension Vehicle over 91 Days of Storage in Glass and Plastic Bottles and Plastic Syringes $\left(25^{\circ} \mathrm{C}\right)$ and in Glass and Plastic Bottles $\left(4^{\circ} \mathrm{C}\right)^{*}$

\begin{tabular}{|c|c|c|c|c|c|}
\hline \multirow[b]{2}{*}{ Study Day } & \multicolumn{2}{|c|}{ Glass Bottles } & \multicolumn{2}{|c|}{ Plastic Bottles } & \multirow{2}{*}{$\frac{\text { Plastic Syringes }}{25^{\circ} \mathrm{C}}$} \\
\hline & $25^{\circ} \mathrm{C}$ & $4^{\circ} \mathrm{C}$ & $25^{\circ} \mathrm{C}$ & $4^{\circ} \mathrm{C}$ & \\
\hline $\begin{array}{l}0 \text { (initial measured concentration; } \\
\mathrm{mg} / \mathrm{mL}) \dagger\end{array}$ & $0.987 \pm 0.051$ & $0.987 \pm 0.051$ & $0.987 \pm 0.051$ & $0.987 \pm 0.051$ & $0.987 \pm 0.051$ \\
\hline 7 & $100.1 \% \pm 2.3 \%$ & $99.1 \% \pm 1.9 \%$ & $100.3 \% \pm 3.1 \%$ & $97.5 \% \pm 3.6 \%$ & $97.7 \% \pm 3.8 \%$ \\
\hline 14 & $99.6 \% \pm 2.2 \%$ & $99.1 \% \pm 1.9 \%$ & $96.8 \% \pm 2.3 \%$ & $99.3 \% \pm 2.0 \%$ & $99.2 \% \pm 4.3 \%$ \\
\hline 21 & $99.5 \% \pm 2.2 \%$ & $98.6 \% \pm 3.3 \%$ & $98.8 \% \pm 1.9 \%$ & $100.1 \% \pm 1.2 \%$ & $100.0 \% \pm 1.0 \%$ \\
\hline 28 & $98.1 \% \pm 2.1 \%$ & $99.4 \% \pm 0.9 \%$ & $97.7 \% \pm 2.0 \%$ & $99.6 \% \pm 1.7 \%$ & $99.3 \% \pm 1.3 \%$ \\
\hline 35 & $100.7 \% \pm 2.0 \%$ & $97.9 \% \pm 4.4 \%$ & $97.1 \% \pm 1.1 \%$ & $100.7 \% \pm 3.8 \%$ & $96.5 \% \pm 2.7 \%$ \\
\hline 49 & $99.3 \% \pm 3.0 \%$ & $100.7 \% \pm 3.6 \%$ & $97.7 \% \pm 2.4 \%$ & $99.4 \% \pm 2.6 \%$ & $101.1 \% \pm 0.7 \%$ \\
\hline 63 & $100.1 \% \pm 3.3 \%$ & $97.2 \% \pm 0.9 \%$ & $98.4 \% \pm 2.0 \%$ & $100.7 \% \pm 2.5 \%$ & $99.2 \% \pm 2.3 \%$ \\
\hline 77 & $98.7 \% \pm 2.6 \%$ & $98.8 \% \pm 0.7 \%$ & $98.9 \% \pm 2.1 \%$ & $98.5 \% \pm 0.9 \%$ & $98.4 \% \pm 1.1 \%$ \\
\hline 91 & $97.7 \% \pm 2.0 \%$ & $99.0 \% \pm 3.0 \%$ & $98.9 \% \pm 3.4 \%$ & $97.8 \% \pm 1.2 \%$ & $99.9 \% \pm 1.0 \%$ \\
\hline
\end{tabular}

*Measured concentration on day 0 is reported as mean \pm standard deviation of 3 samples, analyzed in duplicate. Percent of initial measured concentration on all study days was calculated from the mean \pm standard deviation of 3 samples, analyzed in duplicate. †Nominal initial concentration of all suspensions was $1.0 \mathrm{mg} / \mathrm{mL}$.

\section{References}

1. DiPiro J, Talbert RL, Yee G, Matzke G, Wells B, Posey LM. Pharmacotherapy: a pathophysiologic approach. 8th ed. New York (NY): McGraw-Hill; 2011.

2. Dexamethasone. In: American hospital formulary service drug information. Bethesda (MD): American Society of Health-System Pharmacists; 2011. p. 3074 .

3. Chou JWL, Décarie D, Dumont RJ, Ensom MHH. Stability of dexamethasone in extemporaneously prepared suspensions. Can J Hosp Pharm. 2001; 54(2): 96-101.
4. Ora-Blend ${ }^{\circledR}$ flavored oral suspending vehicle. Minneapolis (MN): Paddock Laboratories, LLC; 2010 [cited 2013 Nov 28]. Available from: www.perrigo. com/files/rx/pdfs/pds171-Ora\%20Blend\%20Sell\%20Sheet.pdf

5. Ora-Blend ${ }^{\circledR}$ SF flavored sugar-free oral suspending vehicle. Minneapolis (MN): Paddock Laboratories, LLC; 2010 [cited 2013 Nov 28]. Available from: www.perrigo.com/files/rx/pdfs/pds172-Ora\%20Blend\%20SF\%20Sell \%20Sheet.pdf

6. Medisca's oral bases. Plattsburgh (NY): Medisca Inc; [cited 2013 Nov 28]. Available from: http://files.medisca.com/promotionsca/oral_bases/oral_bases_ flyer_mca.pdf 
Mary H H Ensom, BS(Pharm), PharmD, FASHP, FCCP, FCSHP, is Professor, Faculty of Pharmaceutical Sciences, and Distinguished University Scholar, The University of British Columbia; and Clinical Pharmacy Specialist, Department of Pharmacy, Children's and Women's Health Centre of British Columbia, Vancouver, British Columbia. She is also the Editor of the CJHP.

Diane Décarie, BSc, is a Research Consultant, Department of Pharmacy, Children's and Women's Health Centre of British Columbia, Vancouver, British Columbia.

Funding: Funding for this project was provided as an unrestricted educational grant from Medisca Pharmaceutique Inc.
Competing interests: Other than grant support, no competing interests were declared.

Acknowledgments: We would like to thank Mr. Spencer Tuttle for project logistics.

Address correspondence to:

Dr Mary H H Ensom

Pharmacy Department OB7

Children's and Women's Health Centre of British Columbia 4500 Oak Street

Vancouver BC V6H 3N1

e-mail: ensom@mail.ubc.ca

\section{CISADL 2013}

\section{Order your copy of the 2013 Canadian Investigational \& Special Access Drug List today!}

\section{Please use the CSHP order form found online at CSHP.ca to place your order.}

The CISADL is a compilation of drugs that are currently not marketed in Canada and may have Investigational or Special Access status with Health Canada. This list is not endorsed by Health Canada's Special Access Program. For precise information about the regulatory status of a drug, contact the Special Access Program directly. Entries to the list are contributed to by several Drug Information Centers across Canada and by Canadian drug manufacturers. In cases where non-marketed drugs do not appear on the list, foreign references should be consulted. The content of the list includes generic name and strength/concentration, dosage form, pharmacology/therapeutic use, trade and code name, source (manufacturer/distributor), and comments. Available in English only.

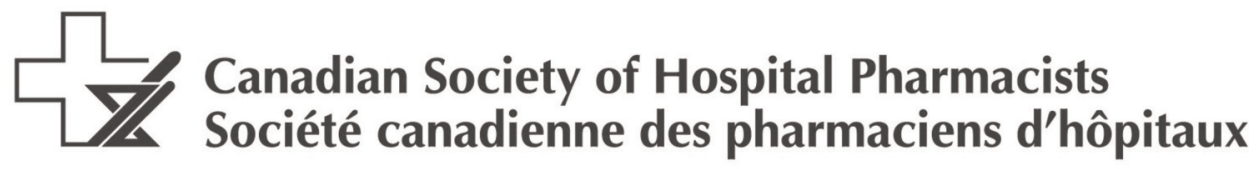

